International Journal of Physical Sciences and Engineering
Available online at http://sciencescholar.us/journal/index.php/ijpse
Vol. 2 No. 3, December 2018, pages: 51 61
e-ISSN : 2550-6943, p-ISSN : 2550-6951
https://doi.org/10.29332/ijpse.v2n3.188

\title{
Utilization of Bali Traditional Acoustic Tools as Physical Repellent of Bird Pest on Rice Paddy Crop
}

\author{
I Gde Antha Kasmawan a, I Wayan Supartha b , I Nyoman Wijaya c, Ida Ayu Dwi Giriantari d
}

Article history: Received 15 April 2018, Accepted: 30 August 2018, Published: 20 September 2018

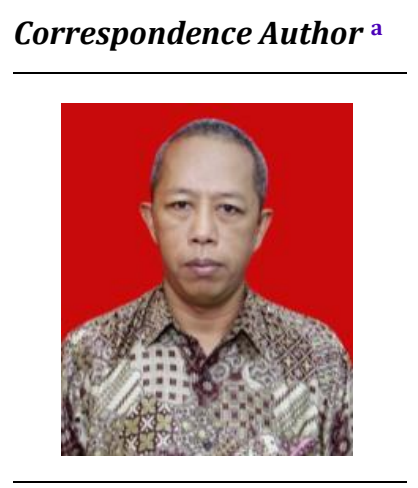

Keywords

Bali traditional acoustic tools;

Bird pest;

Local wisdom;

Environmentally friendly;

Rice paddy crop;

\begin{abstract}
The purpose of this research is to identify the diversity of Bali's traditional acoustic tools as a physical repellent of bird pest on rice paddy crop that characterizes local Balinese wisdom as well as analyze their existence and possible modification of tools. The method used is survey method through questionnaire and direct interview to farmers (age 60 years and over) in three rice paddy crop centers, namely Tabanan (6 villages), Badung (5 villages), and Gianyar ( 2 villages) regencies. Based on the survey of 127 respondents, 52 people from Tabanan, 42 from Badung and 33 from Gianyar, it was found that the most common types of Bali's traditional acoustic tools used to repel bird pest by farmers, in Balinese terms, are kepuakan (91.3\%), followed by pindekan $(5.5 \%)$, pecut $(2.4 \%)$ and kulkul $(0.8 \%)$. Kepuakan is more chosen because it is considered more effective and comfortable to use to repel bird pest in rice paddy crop. According to the respondents, the most effective sequence of acoustic tools from high to low is kepuakan (80.3\%), followed by pecut $(10.2 \%)$, pindekan (8.7\%), kulkul ( 0.8 and for the comfort of the use of tools, the order is kepuakan $(85,8 \%)$. followed by pindekan $(9.4 \%)$, kulkul $(3.9 \%)$ and pecut $(0.8 \%)$. All the traditional tools are the result of handicrafts Bali farmers use natural materials and are a form of the local wisdom of Balinese farmers that are certainly environmentally friendly.
\end{abstract}

e-ISSN: 2550-6943, p-ISSN: 2550-6951 @ Copyright 2018. The Author. SS Journals Published by Universidad Técnica de Manabí. This is an open-access article under the CC BY-SA 4.0 license (https://creativecommons.org/licenses/by-sa/4.0/) All rights reserved.

a Department of Physics, Faculty of Mathematics and Natural Sciences, Udayana University, Indonesia

b Department of Agroecotechnology, Faculty of Agriculture, Udayana University, Indonesia

c Department of Agroecotechnology, Faculty of Agriculture, Udayana University, Indonesia

d Department of Electrical Engineering, Faculty of Engineering, Udayana University, Indonesia 


\section{Contents}

Abstract

1. Introduction

2. Materials and Methods.

3. Results and Discussions..

3.1 Effectiveness

3.2 Comfort levels.

3.3 Modify Tools.

4. Conclusion...

Acknowledgements..

References

Biography of Authors

\section{Introduction}

Bali is one of the islands in Indonesia where the majority of the population work as rice farmers. Agricultural management based on the local wisdom of Balinese Hindu culture has made Bali one of the national rice producers as well as supporting Bali as a tourist destination. One of the Balinese people's guidelines for achieving a happy life in all things with no damage to nature including also in terms of agricultural management is the concept of tri hita karana (the three causes of happiness) comes from Hinduism. The concept includes three elements, in local terms, namely parahyangan, pawongan and palemahan, each of which teaches how to maintain human relationships with God, humans with humans and humans with nature in order to remain harmonious (Sukarma, 2016; Suarta, et al., 2018). The concept is also applied in the control of pests and plant diseases in the form of religious ceremonies commonly known as the ceremony of nangluk merana (Lestari, et al., 2017). Associated with pests, other than insects, the types of pests that commonly attack rice plants in Bali are rats and birds. Rats attack rice plants during the night while the birds during the daytime. Especially in bird pest control, Balinese farmers use traditional equipment including traditional acoustic tools that have been used for generations. The tools are made of local bamboo or a combination of some natural materials that exist in the surrounding environment.

Birds commonly attacking rice paddy crop in Indonesia including Bali are grain-eating birds of the bondol family (Lonchura sp.), whose habitat includes rice fields, plantations, moorings and bushes (Ayat, 2011). As a pest, the birds come to the rice paddy crop in clusters with the number of tens to thousands. The Flock of birds is attacking rice plants when the plant is entering the generative phase, which is when the grains of rice are still like milk until the grains ready for harvest. Bird pest attacks can cause serious harm to farmers. The severe damage that can be inflicted on rice paddy crop is the loss of grain in the panicle of rice which ultimately results in the decline of the harvest result.

Efforts in bird pest control in rice paddy crop in Indonesia including Bali has been done in various ways. Some of them are through the arrangement of rice cropping pattern simultaneously, direct bird catching, destruction of bird's nest, the use of nylon net covering all rice plants, the installation of visual devices as locally known as lelakut (scarecrow) or various colorful flags made of plastic/cloth sheets and the use of audio equipment in the form of traditional acoustic tools or a series of cans containing pebbles.

Acoustically, bird pest control can be done by interfering with bird communications considering that the most flexible and effective channel for bird communication is through hearing to allow for behavioral or physiological changes in birds (Waldvogel, 2001). Acoustically bird control is not intended to destroy birds but only to repel or frighten birds. Efforts in frightening birds are more effective when the sounds used have a range of frequencies that birds can hear, have a high level of sound pressure and can carry relevant messages for birds to go immediately (Beason, 2004). In terms of bird control, the type of sound used is audible (audioconic), given that the hearing sensitivity of birds is narrower than that of human hearing, ranging from 1-5 kHz (Bouteloup, et al., 2011); Dooling, 2002). In addition, birds are naturally susceptible to fear with unusual and unpredictable events especially when events that give the impression of dangerous and frightening. The success rate in scaring the birds also depends on habituation factors. Therefore, the use of various bird repellents is highly recommended to maximize the expected results (Tracey, 2007; Ariani, et al., 
2018). The combination of the use of these tools is also necessary so that birds are not easy to ignore its existence (Brittingham, 2010).

In Bali, there are three rice paddy crop centers, namely Tabanan, Badung and Gianyar regencies all of which have similar local wisdom in bird pest control acoustically. The objective of the study is to identify the Bali's traditional acoustic tools used as a physical repellent of bird pest on rice paddy crop and analyze their existence and the possibility of modification of the tools.

\section{Materials and Methods}

The study focused on three rice paddy crop centers in Bali, namely Tabanan regency (6 villages), Badung Regency ( 5 villages) and Gianyar regency ( 2 villages). Tabanan covers Jegu, Buwit, Buruan, Tajen, Tunjuk and Biaung villages, Badung covers Baha, Gulingan, Sobangan, Werdi Buana and Mengwi villages and Gianyar covers Temesi and Bitera villages. The total number of respondents is 127 rice farmers who have been aged 60 years and over (elderly). The research method used is a survey method with purposive sampling technique by distributing questionnaires and direct interviews to farmers whose fields have been or are often attacked by bird pest. The selection of respondents from elderly people is based on the consideration that they have understood the types of traditional acoustic tools that have been used as a physical repellent of bird pest and are considered to have a lot of experience in their use in the field. The research data obtained are data about Bali's traditional acoustic tools which are often used to repel bird pest, what materials are used, how to make them, how to use them and the existence of these tools at present. Measurement of the sample dimension of these tools is also done. Through these surveys and interviews, the effectiveness and comfort of the use of these tools are also reported.

\section{Results and Discussions}

Based on the results of in-depth interviews on a preliminary survey of the three leaders of traditional farmers, who each named I Wayan Surata (origin of Temesi Village, Gianyar), I Wayan Roteg (origin of Sobangan Village, Badung) and I Made Sudiadnyana (origin of Jegu Village, Tabanan), there are eight acoustic tools commonly used by Balinese farmers to repel bird pest in rice fields, in Balinese terms, namely kepuakan, krincingan, pindekan, kronongan, pecut, jedar-jedaran or lom-loman, kulkul and gegedigan. All of the acoustic tools and their explanations are presented in Table 1.

Table 1

Eight acoustic tools commonly used by Balinese farmers to repel bird pest in rice paddy crop

\begin{tabular}{|c|c|c|}
\hline No. & $\begin{array}{l}\text { Types of the acoustic } \\
\text { tools }\end{array}$ & Description \\
\hline 1 & Kepuakan & $\begin{array}{l}\text { A traditional acoustic tool is made from one local bamboo segment, one end } \\
\text { is halved and the other end is partially removed as a handle. The tool had } \\
\text { existed before the } 1960 \mathrm{~s} \text {. }\end{array}$ \\
\hline 2 & Kulkul & $\begin{array}{l}\text { A traditional acoustic tool is made from one local bamboo segment that is } \\
\text { given a longitudinal hole in the center of the bamboo side. The tool had } \\
\text { existed before the } 1960 \mathrm{~s} \text {. }\end{array}$ \\
\hline 3 & Kronongan & $\begin{array}{l}\text { A propeller-like acoustic tool equipped with a used metal tin on the back } \\
\text { that can produce rhythmic and rowdy sounds, made from a combination of } \\
\text { plastic/metal and bamboo plates (emerged after the 1990s). }\end{array}$ \\
\hline 4 & Krincingan & $\begin{array}{l}\text { An acoustic tool made from a series of used metal cans filled with pebbles } \\
\text { and when shaken can produce loud noises (emerged after the 2000s). }\end{array}$ \\
\hline 5 & $\begin{array}{l}\text { jedar-jedaran or lom- } \\
\text { loman }\end{array}$ & $\begin{array}{l}\text { An acoustic tool similar to a cannon equipped with electronic ignition, } \\
\text { when fired can produce a loud impulsive sound, made from a combination } \\
\text { of used can and polyvinyl chloride (PVC) pipe with a methylated spirits }\end{array}$ \\
\hline
\end{tabular}

Kasmawan, I. G. A., Supartha, I. W., Wijaya, I. N., \& Giriantari, I. A. D. (2018). Utilization of Bali traditional acoustic tools as physical repellent of bird pest on rice paddy crop. International Journal of Physical Sciences and Engineering, 2(3), 51-61. https://doi.org/10.29332/ijpse.v2n3.188 
fuel. In some places, the use of such tools has been banned especially in areas near poultry cages (emerged after the 2000s).

6 Pindekan

A traditional acoustic tool such as a propeller made from a combination of local wood and bamboo materials (existed before the 1960s).

$7 \quad$ Pecut A traditional acoustic tool such as a whip made from a combination of palm leaves stick, ropes and bamboo (existed before the 1960s).

8 Gegedigan A simple acoustic tool in the form of used metal sheets (zinc) is framed and when struck with a stick can produce noise (emerged after the 2000s).

Source: a preliminary survey with farmers

Among the eight types of the tools, four of them are Bali's traditional acoustic tools that have been passed down from generation to generation. The four types of traditional tools are kepuakan, pindekan, pecut and kulkul. The identification of the four tools related to the material used, the type of sound produced, the users and the range of tool life are presented in Table 2. Recapitulation of data related to the utilization of these four types of traditional tools as a physical repellent of bird pest on rice paddy crop is presented in Table 3 . The data were obtained from the survey of 127 respondents ( 52 people from Tabanan, 42 from Badung and 33 from Gianyar) using purposive techniques sampling through the distribution of questionnaires and direct interviews.

Table 2

Identify the four Bali's traditional tools used as a physical repellent of bird pest on rice paddy crop

\begin{tabular}{|c|c|c|c|c|}
\hline $\begin{array}{c}\text { Type of traditional } \\
\text { tools }\end{array}$ & Materials used & $\begin{array}{l}\text { Type of sound } \\
\text { produced }\end{array}$ & User & $\begin{array}{c}\text { Range of } \\
\text { tool life } \\
\text { (year) }\end{array}$ \\
\hline Kepuakan & bamboo & clapping sound & man and woman & $1-4$ \\
\hline Kulkul & bamboo & knocking sound & man and woman & $1-5$ \\
\hline Pindekan & $\begin{array}{l}\text { bamboo and other } \\
\text { materials }\end{array}$ & whistle sound & man & $1-2$ \\
\hline Pecut & $\begin{array}{l}\text { bamboo and other } \\
\text { materials }\end{array}$ & blast sound & man & 1 \\
\hline
\end{tabular}

Table 3

Recapitulation of survey results related to the use of Bali's traditional acoustic tools as a physical repellent of bird pest on rice paddy crop in three regencies (Gianyar, Badung, and Tabanan)

\begin{tabular}{lcccc}
\hline $\begin{array}{c}\text { Type of traditional } \\
\text { tools }\end{array}$ & $\begin{array}{c}\text { Gianyar regency } \\
\text { Regency }\end{array}$ & $\begin{array}{c}\text { Badung } \\
\text { Tabanan Regency }\end{array}$ & $\begin{array}{c}\text { Number of } \\
\text { respondents }\end{array}$ \\
\hline $\begin{array}{l}\text { Choice of farmers for the most widely used traditional tool } \\
\text { Kepuakan }\end{array}$ & 30 & 38 & 48 & 116 \\
Kulkul & 0 & 1 & 0 & 1 \\
Pindekan & 0 & 3 & 4 & 7 \\
Pecut & 3 & 0 & 0 & 3 \\
\hline Choice of farmers for the most effective traditional tool & 35 & 46 & 102 \\
Kepuakan & 21 & 1 & 0 & 1 \\
Kulkul & 0 & 5 & 6 & 11 \\
Pindekan & 0 & 1 & 0 & 13 \\
Pecut & 12 & 35 & 42 & 109 \\
\hline Choice of farmers for the most comfortable traditional tool & 7 & 12 \\
Kepuakan & 32 & 5 & 0 & 1 \\
Kulkul & 0 & 0 & 3 & 5 \\
Pindekan & 1 & 2 & & \\
Pecut & 0 & & & \\
\hline
\end{tabular}


Based on Table 1, the four traditional Balinese tools are handicrafts from Balinese farmers made from natural materials using simple technology. All of these tools are estimated to have existed after the application of the paddy rice planting process twice a year or since bird pest needs to be controlled. The use of these four tools is mostly intended to repel or disturb the birds and not to destroy the birds so that the conservation of nature is maintained in accordance with the concept of tri hita karana and before the tools are used in the field, first performed the ceremony in accordance with local customs and culture with the aim that its use is more effective.

Based on the results of the survey in Table 2 and some additional notes during the interview, a more detailed description of the four traditional acoustic tools was obtained as in the following description.

Kepuakan: This acoustic tool is made of local bamboo materials and when played can produce single or consecutive clapping sound. Types of bamboo commonly used in the made of the tool are a tali bamboo (Giganlochloa apus) and jajang bamboo (Giganlochloa ridleyi). Kepuakan from Tabanan and Badung are made using only tali bamboo while for Gianyar using jajang bamboo as an alternative other than tali bamboo. The size (dimension) of the tools varies according to the types of bamboo used, the length is $39-75 \mathrm{~cm}$, the diameter is $5-6 \mathrm{~cm}$ and the thickness is $0.4-0.6 \mathrm{~cm}$. The tools are made by cutting a bamboo segment and splitting one end into two parts to form the same parts. At the other end is partially removed which is intended as a handle when the device is played. This tool can be played with one or two hands while walking around the rice fields. Kepuakan can be played by all ages, small children to adults, men, and women. Kepuakan can be played in large quantities by installing each of these tools on bamboo stalks along the rice fields and connecting them to each other using a long string. When the connecting rope is pulled-out then the whole tool will sound so that it can give noise effects along the rice fields. There are generally two shapes of kepuakan, namely the shape of the segment and without the segment as shown in Fig. 1.

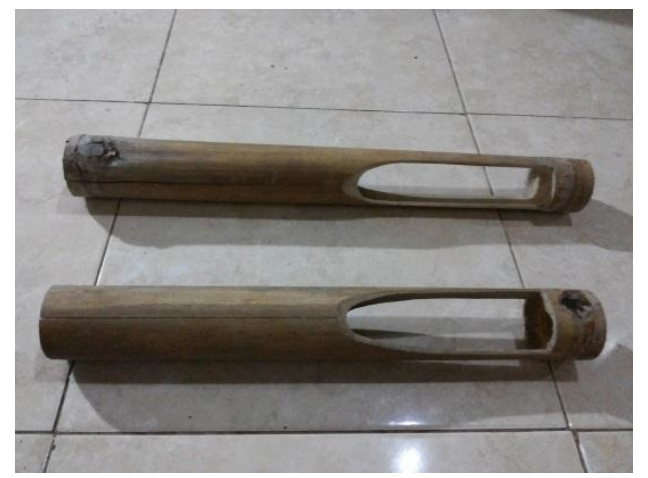

Figure 1. Two shapes of kepuakan

Pindekan: This kind of propeller tool is made of a combination of bamboo and wood driven by wind power. The blades of pindekan are made of lightweight and durable wood types. Types of wood that satisfy these qualifications and commonly used are waru wood (Thespesia popunea) or sengon wood (Albizia chinensis). After the wood is cut and split according to the desired size, the pindekan blades are formed by sharpening the wood to a symmetrical elongated flat shape with a small hole in the middle. The center hole is used as the installation of the pindekan rotary axis. The elongated flat blade shape is intended to make the power of the play more maximal when exposed to the wind blowing through it. The dimensions of the pindekan blades can be about 1-2 $\mathrm{m}$ in length, 5-8 $\mathrm{cm}$ in wide, and 1-3 cm in thickness. For installation, pindekan mounted on a bamboo equipped with a kind of steering tool on the back so that wind power obtained becomes larger. So to operate pindekan in order to produce a strong whistle sound, wind power is absolutely necessary. For that purpose, pindekan that has been attached to a bamboo is usually plugged in the highest rice field or next to kubu (small hut in the rice field area). Special skill is required for the making process and installation of the tool because it concerns acoustic and aesthetic problems. This work is generally done by adolescents or adult males. Success in this work greatly determines the physical appearance and sound characteristics that can be generated by pindekan. Currently, pindekan can still be found in rice fields in Badung and Tabanan regencies.

Kasmawan, I. G. A., Supartha, I. W., Wijaya, I. N., \& Giriantari, I. A. D. (2018). Utilization of Bali traditional acoustic tools as physical repellent of bird pest on rice paddy crop. International Journal of Physical Sciences and Engineering, 2(3), 51-61. https://doi.org/10.29332/ijpse.v2n3.188 
The shape of the pindekan before being installed and after installation on long bamboo complete with accessories and tail as the wind direction steering is shown in Figures 2.

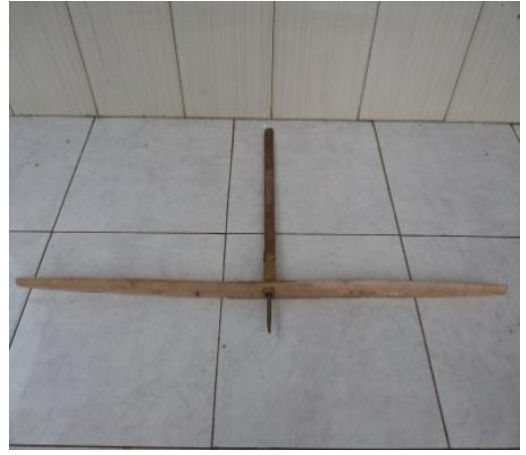

(a)

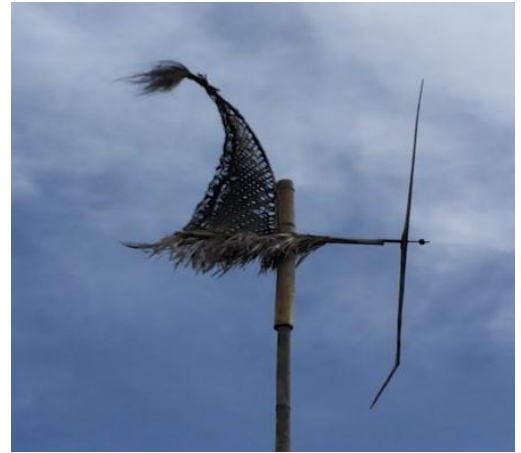

(b)

Figure 2. The basic shape of pindekan and Installation of pindekan complete with accessories

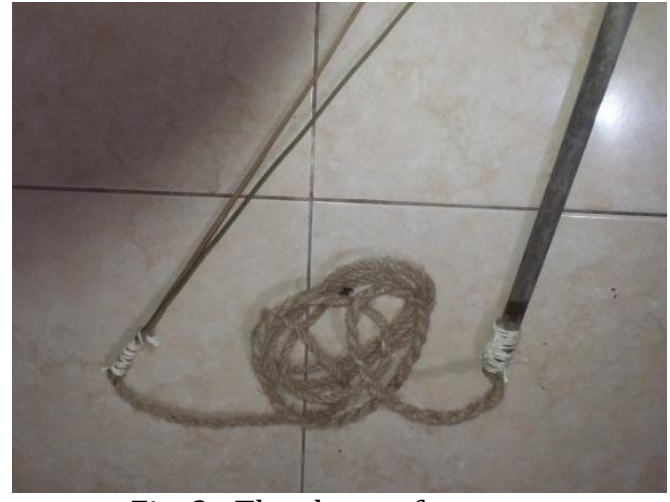

Fig. 3- The shape of pecut

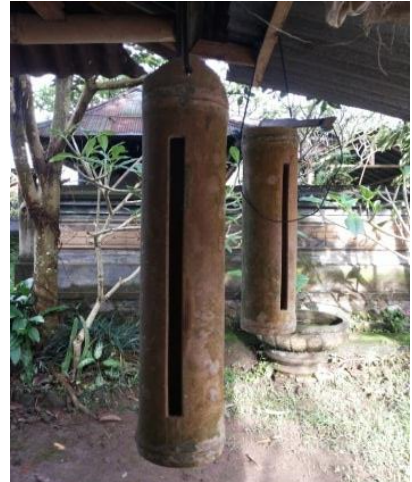

Fig. 4- Two tools of kulkul

Pecut: This tool consists of three main parts, namely the base, the middle, and the head of the pecut that when played, the tool can produce a loud sound like a balloon blasted. The material of the head of the whip is usually taken from the bone of the leaves of the palm tree (Arenga pinnata) which in Indonesia is known as lidi. The middle part is a rope that can be made from either coconut or bamboo fibers have been woven. The pecut making procedure begins with the selection of two lidi with the same length (the length of lidi can range from about 100-120 cm). The two ends of lidi are combined and then connected to one end of the rope $(2.5 \mathrm{~m}$ in length and $0.5-0.8 \mathrm{~cm}$ in diameter). The other end of the rope is tied to the top of the bamboo ( $4 \mathrm{~m}$ in length and $2-4 \mathrm{~cm}$ in diameter). Special skills are required to play pecut where the lower end of the bamboo is plugged in the ground and the center of the bamboo is rotated in such a way that it produces a horizontal rotation of the rope and the head of the pecut tight enough. After the desired rotational speed is obtained, suddenly the rotation direction is reversed towards the previous rotation so that the two lidi on the head of the pecut collide and sound like a loud explosion. When less careful in playing this tool, the user can be hurt like hit by a whip. This can be caused by a rope wrapped around the user's body or improper rotation of pecut. Because of the process of making and playing it that is considered quite complicated (only done by male adults), the tool is currently very rarely used and difficult to find among farmers. The use of pecut as a bird pest repellent has only been done by farmers from Gianyar. The shape of pecut is shown in Figure 3.

Kulkul: For purposes in the rice fields, kulkul can be made using any local bamboo. This tool can be made quite easily, ie by cutting one bamboo segment with both ends closed. At the top end is formed a handle or made a hole to insert the rope hanger while in the center of the bamboo is also made a long hole as an air hole. The hole is usually made lengthwise with a width of $1-2 \mathrm{~cm}$ and a length of 20-40 cm according to the size of the bamboo used. The size of kulkul according to the types of bamboo are used, generally has a length of 40-60 cm with a diameter of $6-12 \mathrm{~cm}$. Kulkul is played with two hands, one hand holding handle of the tool and the other 
hand hitting it using a stick. When kulkul is used to repel the birds, farmers hit the tool while walking around the rice field similar to when playing kepuakan. Kulkul, as well as kepuakan, can also be played by all ages (small children to adults, both men, and women). Currently, this tool is also very rarely used to repel bird pest because it is considered less practical than kepuakan. The existence of bamboo kulkul currently more widely used as a means of security that hung in front of the house. In the event of a disruption of similarity or fire the tool can be beaten continuously as an important signal that there has been a danger and should be given immediate help. Two tools of kulkul hung in front of the house are shown in Figure 4.

According to Table 3, the sequence of traditional acoustic tools most commonly used by Balinese farmers to repel bird pest is kepuakan (91.3\%), followed by pindekan (5.5\%), pecut (2.4\%) and kulkul (0.8\%). For effectiveness of the tools used, the most effective sequence of acoustic tools is kepuakan (80.3\%), followed by pecut $(10.2 \%)$, pindekan $(8.7 \%)$ and kulkul $(0.8 \%)$. Meanwhile, for convenient use of the tools, the most convenient tool used from the highest order to low is kepuakan (85.8\%), followed by pindekan (9.4\%), kulkul (3.9\%) and pecut (0.8\%). Graphically, the whole survey results shown in Figure 5.

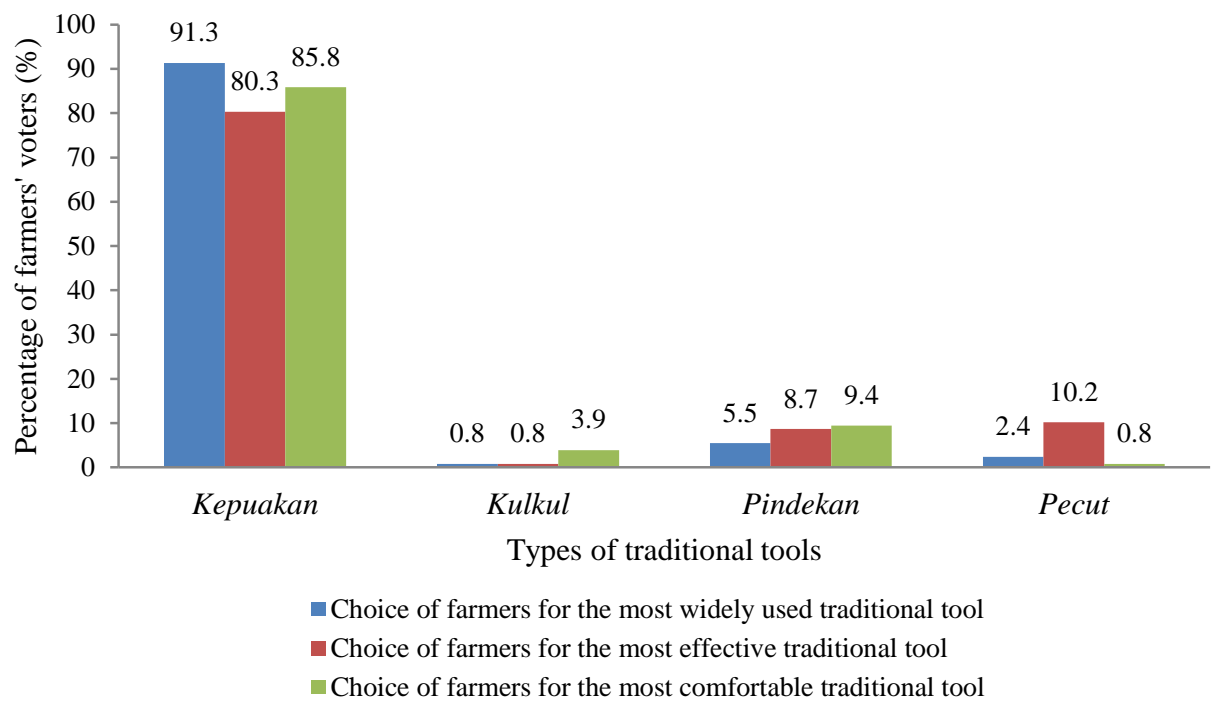

Figure 5. Graph of survey results on the use of Bali's traditional acoustic tools as a physical repellent of bird pest on rice paddy crop in three regencies (Gianyar, Badung, and Tabanan)

Based on the Graph in Figure 5, kepuakan is the most widely used traditional acoustic tool to repel bird pest, followed by pindekan, pecut and kulkul. The choice of respondents is based on several considerations, namely the ease of obtaining the raw materials used, ease of making the tools, ease of using the tools, the effectiveness of its use and user comfort when the tool is used. Among the five factors, effectiveness and convenience are more considered.

\subsection{Effectiveness}

The use of kepuakan is considered the most effective way to repel birds because it can give a frightening impression on birds and does not seem visually monotonous. In addition, the pounding sound can be easily varied by the user. When it is used, farmers rarely stay in one place. They usually always walk around the rice fields and play kepuakan closer to the flock of birds that perch on the rice plants until the birds go away. When repelling birds, farmers often brandished kepuakan so that it gave a frightening impression to the flock of birds that ultimately caused the birds to fly away. In addition, kepuakan is considered effective because the user can play several tools at once so as to provide a rowdy noise everywhere with an irregular duration that makes the birds disturbed and go away. Pecut are considered less effective than kepuakan because pecut are

Kasmawan, I. G. A., Supartha, I. W., Wijaya, I. N., \& Giriantari, I. A. D. (2018). Utilization of Bali traditional acoustic tools as physical repellent of bird pest on rice paddy crop. International Journal of Physical Sciences and 
not widely known to farmers and only certain people can use them. Nevertheless, the use of pecut is considered more effective than pindekan and kulkul. This is because pecut can produce an impulsive sound when played. In addition, the sweeping movements of pecut can also reach areas with a wide radius, at least 5 meters, or depending on the length of the rope used. The impulsive sounds and the sweeping movements of pecut can give a frightening impression on the bird so the birds go away. Pindekan is considered to be less effective than kepuakan dan pecut because it can only sound when there is a wind through it. Pindekan is considered more effective than kulkul because the tool can produce a loud whistling sound. Some of pindekan mounted in the rice field area can produce a different color of whistle sounds that can disturb the bird's calm so birds go from the area. Kulkul considered less effective because of the resulting sound less varied. In addition, to hit some kulkul requires a lot of people because one user can only hit one kulkul.

\subsection{Comfort levels}

Kepuakan is considered the most comfortable to use to repel the birds because of their shape and handle according to the size of the human body and hands. The length of a segment of bamboo is generally not longer than the adult's length and when held vertically will not touch the floor. This is important because it will not interfere with the user's walking activity especially when kepuakan not used. The handle of kepuakan is also shaped in such a way that the tool is comfortable as grasping the sticks in general, feels comfortable in the hand and does not make the finger scratched or pinched. In addition, when kepuakan is used, the resulting sound is still comfortable in the user's ear even though it sounds like a loud clapping sound (the sound pressure level is about $80-90 \mathrm{~dB}$ at a distance of $40 \mathrm{~cm}$ ). Kepuakan, made from dried bamboo, is also considered convenient to use because it is easy to carry because the weight is not too large (about $0.4-0.7 \mathrm{~kg}$ ). Farmers considered that pindekan less comfortable to use compared to kepuakan but more comfortable when compared to kulkul and pecut. This is because pindekan is driven by wind power so that the user cannot control the rotation of the tool and the sound it produces cannot be set by the user. Pindekan can spin and sound both day and night. At an unwanted moment, the sound of the noise produced by some pindekan is considered very disturbing. If the area of rice paddy crop is near the village, the noise is certainly very disturbing the comfort of the surrounding residents, especially at night. The use of kulkul to repel birds is considered less comfortable compared to kepuakan and pindekan. This is because generally, kulkul have heavier weight compared with kepuakan and pindekan. In addition, the use of kulkul should be with two hands so it can be tiring when using it for long periods of time. However, the use of kulkul is considered more comfortable compared to pecut because it is easier to play and does not endanger the user. Pecut is considered most uncomfortable to use because the tool is considered to be harmful to its users. For novice users, an error in using a pecut can lead to binding of rope of the tool around the user's body and can cause a scratch on the user's body especially on the hands, body, or even the face.

\subsection{Modify Tools}

The effectiveness of the use of traditional acoustic tools to repel bird pest in rice fields can be improved by modifying the tools to qualify sounded, detected, and relevant conditions ${ }^{5}$. In addition, some tools can be used at once to avoid habituation (Bouteloup, et al., 2011). Among the four Bali's traditional acoustic tools often used by farmers, two of them, namely kepuakan and pindekan are more desirable to be modified. While the other two tools, namely pecut and kulkul received less attention to be developed. For kepuakan, modification of the tool can be done by giving layer the inside with a metal slab of a certain thickness to produce louder and shrill sounds that can be more influential in bird hearing. On the outside of kepuakan can be colored with a shiny paint color to add a frightening impression on the bird. It is advisable to use multiple kepuakan tools at once with different sound colors and be randomly alternated so as to prevent habituation and interfere with bird communication. To obtain maximum results, the color and the thickness of the metal plates on each kepuakan are distinguished from each other. For pindekan, installation of blades and accessories can be changed at any time to avoid habituation. Modifications to the blades of pindekan have been made by bending one of the blades to produce a distinctive whistle sound. In addition, the width of the blades can be modified 
using layers of metal sheets of different colors to obtain the desired width and color of the blades. The same thing can be done on the accessories pindekan, shape and color can be changed. Installation of pindekan with different whistle sounds and randomly alternately will certainly give a frightening effect on the birds and when the installation of more pindekan would be very disturbing bird communication.

\section{Conclusion}

There are four types of traditional Balinese acoustical instruments from eight acoustic tools that have been used to repel bird pest on rice paddy crop. The four tools are kepuakan, pindekan, pecut and kulkul. The survey of 127 respondents who have been aged 60 years and over showed that the sequence of traditional acoustic tools most commonly used is kepuakan (91.3\%), followed by pindekan (5.5\%), pecut (2.4\%), and kulkul $(0.8 \%)$. The choice of respondents is based more on the effectiveness and convenience factor when the tool is used in the field. All the traditional tools are made from natural materials using simple technology and are the result of handicrafts of farmers who have Balinese characteristics so that these tools are one form of the local wisdom of Balinese farmers who are certainly environmentally friendly.

\section{Acknowledgments}

We are grateful to Kemenristekdikti from Indonesia through LPPM of Udayana University Bali who has funded the Doctoral Dissertation Grant of 2017. We also thank all respondents and anyone who has participated in the research.

Kasmawan, I. G. A., Supartha, I. W., Wijaya, I. N., \& Giriantari, I. A. D. (2018). Utilization of Bali traditional acoustic tools as physical repellent of bird pest on rice paddy crop. International Journal of Physical Sciences and 


\section{References}

Ariani, R. P., Darmawan, D. P., Atmaja, N. B., \& Wijaya, I. A. S. (2018). Balinese traditional culinary promotes food skills and its positive impact on tourism vocational school. International Journal of Life Sciences (IJLS), 2(1), 50-62.

Ayat, A. (2010). Burung-Burung Agroforest di Sumatera. World Agroforestry Centre.

Beason, R. C. (2004). What can birds hear?. USDA National Wildlife Research Center-Staff Publications, 78.

Bouteloup, G., Clark, J., Petersen, D. (2011). Assessment of the Effect of Traffic Noise on Wetland Birds: Background Study for the Roe Highway Extension Project. Balcatta: Phoenix Environmental Sciences Pty Ltd.

Brittingham, M. C. (2010). Controlling Birds on Fruit Crops. State College: The Pennsylvania State University.

Dooling, R. (2002). Avian hearing and the avoidance of wind turbines (No. NREL/TP-500-30844). National Renewable Energy Lab., Golden, CO.(US).

Lestari, N. P. N. E., Sunia, W., Wijayanthi, N. W., \& Sinarti, N. N. Empowerment of "subak" in development of sustainable eco-tourism village in bali indonesia.

Suarta, M., Suaria, I. N., \& Sulistiawati, N. P. A. (2018). Build Recommendations Nitrogen Fertilization with the Development of the Period of Durian Crop Replanting. International Journal of Life Sciences (IJLS), 2(1), 111.

Sukarma, I. W. (2016). Tri Hita Karana theoretical basic of moral Hindu. International Journal of Linguistics, Literature and Culture, 2(3), 102-116. Retrieved from

Tracey, J. B., Bomford, M., Hart, Q., Saunders, G., \& Sinclair, R. (2006). Managing bird damage to fruit and other horticultural crops. Commonwealth Government-Department of Agriculture, Fisheries and ForestryBureau of Rural Sciences.

Waldvogel, J. A. (2000). Birdsong playback as a tool for teaching animal behavior. Tested studies for laboratory teaching, 22(22), 247-260. 


\section{Biography of Authors}

\begin{tabular}{|c|c|}
\hline & $\begin{array}{l}\text { I Gde Antha Kasmawan, S.Si., M.Sc. obtained his bachelor's degree in Physics, } \\
\text { Faculty of Mathematics and Natural Sciences, Airlangga University, Surabaya- } \\
\text { Indonesia in } 1993 \text { and obtained a master's degree in Physics at the Bandung } \\
\text { Institute of Technology, Bandung-Indonesia in 2000. Since } 1994 \text { he has been a } \\
\text { lecturer in the Department of Physics, Faculty of Mathematics and Natural } \\
\text { Sciences, Udayana University, Bali-Indonesia and currently taking the Doctor of } \\
\text { Agriculture (S3) Program, Faculty of Agriculture, Udayana University, Bali- } \\
\text { Indonesia. } \\
\text { Email:gdeanthakas@yahoo.com }\end{array}$ \\
\hline & $\begin{array}{l}\text { Prof. Dr. Ir. I Wayan Supartha, MS. obtained a bachelor's degree in Agricultural } \\
\text { Engineering, Faculty of Agriculture, Udayana University, Bali-Indonesia in } 1982 \\
\text { and obtained a master's degree in Agricultural Entomology at the Bogor } \\
\text { Agricultural Institute, Bogor-Indonesia in 1991. In } 1998 \text { he obtained a doctorate at } \\
\text { Bogor Agricultural University, Bogor- Indonesia in the field of Agricultural } \\
\text { Entomology with research topics: Bionomic of Liriomyza huidobrensis (Blanchard) } \\
\text { (Diptera: Agromyzidae) on Potato. He is currently a professor in Agriculture and } \\
\text { as Head of the Integrated Pest Management Laboratory (IPM Lab), Faculty of } \\
\text { Agriculture, Udayana University, Bali-Indonesia. } \\
\text { Email:yansupartha@yahoo.com }\end{array}$ \\
\hline & $\begin{array}{l}\text { Prof. Dr. Ir. I Nyoman Wijaya, MS. obtained a bachelor's degree in Agricultural } \\
\text { Technology, Faculty of Agriculture, Udayana University, Bali-Indonesia in } 1983 \\
\text { and obtained a master's degree in Agricultural Entomology at the Bogor } \\
\text { Agricultural Institute, Bogor-Indonesia in 1992. In } 2003 \text { he obtained a doctorate at } \\
\text { Bogor Agricultural University, Bogor- Indonesia in the field of Agricultural } \\
\text { Entomology with the topic of research: Diaphorina Citri Kuwayama (Homoptera: } \\
\text { Psyllidae): Bioecology and its role as Vector of CVPD (Citrus Vein Phloem } \\
\text { Degeneration) in Siam Citrus Plants. He is currently a professor in the field of } \\
\text { Agriculture, Faculty of Agriculture, Udayana University, Bali-Indonesia. } \\
\text { Email: wijayainyoman1956@gmail.com }\end{array}$ \\
\hline & $\begin{array}{l}\text { Prof. Ir. Ida Ayu Dwi Giriantari, M.Eng.Sc., Ph.D. obtained a bachelor's degree in } \\
\text { Electrical Engineering, Faculty of Engineering, Udayana University, Bali-Indonesia } \\
\text { in } 1990 \text { and obtained a master's degree in Electrical Engineering at the University } \\
\text { of New South Wales, Australia in 1999. In 2003, She obtained a doctorate at the } \\
\text { University of New South Wales, Australia on a topic Research: Condition } \\
\text { Monitoring of Composite Outdoor Insulators using PD Analysis. She is currently a } \\
\text { Professor in Electric Power and Energy System, Department of Electrical } \\
\text { Engineering, Udayana University, Bali-Indonesia. } \\
\text { Email: dayu.giriantari@unud.ac.id }\end{array}$ \\
\hline
\end{tabular}

Kasmawan, I. G. A., Supartha, I. W., Wijaya, I. N., \& Giriantari, I. A. D. (2018). Utilization of Bali traditional acoustic tools as physical repellent of bird pest on rice paddy crop. International Journal of Physical Sciences and Engineering, 2(3), 51-61. https://doi.org/10.29332/ijpse.v2n3.188 